\title{
Particle-associated flagellates: swimming patterns, colonization rates, and grazing on attached bacteria
}

\author{
Thomas Kiørboe ${ }^{1, *}$, Hans-Peter Grossart ${ }^{2}$, Helle Ploug ${ }^{3}$, Kam Tang ${ }^{4}$, Brigitte Auer ${ }^{5}$ \\ ${ }^{1}$ Danish Institute for Fisheries Research, Kavalergården 6, 2920 Charlottenlund, Denmark \\ ${ }^{2}$ Institute of Freshwater Ecology and Inland Fisheries, Alte Fischerhütte 2, 16775 Neuglobsow, Germany \\ ${ }^{3}$ Max Planck Institute for Marine Microbiology, Celsiusstraße 1, 28359 Bremen, Germany \\ ${ }^{4}$ Virginia Institute of Marine Science, Gloucester Point, PO Box 1346, Virginia 23062, USA \\ ${ }^{5}$ Alfred Wegener Institute for Polar and Marine Research, Am Handelshafen 12, 27570 Bremerhaven, Germany
}

\begin{abstract}
Some pelagic flagellates colonize particles, such as marine snow, where they graze on bacteria and thus impact the dynamics of the attached microbial communities. Particle colonization is governed by motility. Swimming patterns of 2 particle-associated flagellates, Bodo designis and Spumella sp., are very different, the former swimming slowly in an erratic, random pattern, and the latter faster and along smooth helixes of variable amplitude and frequency. At spatial scales exceeding ca. $50 \mu \mathrm{m}$, the motility of $B$. designis can be described as a random walk and modeled as diffusion. Spumella sp. shows directional persistence of the helical axes up to a scale of at least about $0.5 \mathrm{~mm}$, and its motility cannot, thus, be characterized as a random walk at such small scales. Motility analyses predicted overall rates at which the 2 flagellates encountered and colonized model particles (4 mm agar spheres) rather well. After initial colonization, the number of flagellates remained approximately constant for $\sim 10 \mathrm{~h}$ or more. In $B$. designis this was due to a density-dependent attachment probability, while in Spumella sp. the declining accumulation rate was better explained by a constant specific detachment rate and a constant (low) attachment probability (12\%). The grazing impact of $B$. designis on attached bacteria was estimated from short-term (4 to $8 \mathrm{~h})$ differences in development of attached bacterial populations in the presence and absence of the flagellate. $B$. designis ingested up to 120 bacteria ind.$^{-1} \mathrm{~h}^{-1}$ (ingestion rate increasing with increasing density of bacteria on the sphere) and had surface area clearance rates of up to $1.3 \times 10^{-4} \mathrm{~cm}^{2} \mathrm{~h}^{-1}$. At flagellate densities typical of marine snow, the implied bacterial grazing mortality exceeds bacterial growth and colonization, suggesting that flagellate grazing controls abundances of attached bacteria.
\end{abstract}

KEY WORDS: Marine snow · Flagellates $\cdot$ Bodo designis $\cdot$ Spumella sp. $\cdot$ Bacteria grazing Resale or republication not permitted without written consent of the publisher

\section{INTRODUCTION}

Marine snow aggregates in the ocean are important as exporters of organic material, but are also sites of elevated microbial activity. Thus, a significant part of the microbial activity in the pelagic environment may occur on or in the vicinity of aggregates (Azam \& Long 2001). Bacteria may cluster in the chemosphere surrounding particles (Jackson 1989, Grossart et al. 2001, Barbara \& Mitchell 2003) and aggregates (Kiørboe \& Jackson 2001) and they may attach to aggregates (Kiørboe et al. 2002), yielding local concentrations that are orders of magnitude higher than bulk ambient concentrations (Alldredge \& Silver 1984, Simon et al. 2002). The bacteria solubilize and remineralize the aggregate, thus reducing vertical fluxes (Smith et al. 1992, Ploug et al. 1999). Heterotrophic flagellates, the most important grazers on pelagic bacteria, also occur at elevated concentrations in and around marine aggregates (Caron et al. 1986, Artolozaga et al. 2000), where they form communities that may be different from those in the ambient water (Caron 1991, Patterson et al. 1993). Many species directly attach to particles, either to feed on the abundant attached bacteria 
(Caron 1987, Artolozaga et al. 2002, Grossart et al. 2003a, Kiørboe et al. 2003), or to exploit the locally enhanced concentrations of free bacteria that are strained more efficiently by attached than by free flagellates (Christensen-Dalsgaard \& Fenchel 2003). Colonization of bacterivorous flagellates may control the abundance of attached bacteria and, hence, impact the rate of aggregate degradation (Kiørboe 2003). Flagellate grazing may also have a more indirect effect on aggregate degradation, since grazing may lead to higher bacterial growth rates and better substrate utilization due to a more efficient nutrient regeneration (Güde 1986).

Despite the significance of the dynamics of attached microbial communities for vertical material fluxes, and the potential role of bacterivorous flagellates for these dynamics, little is known about flagellate particle colonization rates (Kiørboe et al. 2003) and grazing on attached bacteria (Caron 1987, Artolozaga et al. 2002, Kiørboe et al. 2003). For 2 flagellates that are commonly found attached to aggregates, we herein examine motility patterns and how motility leads to particle encounter; we quantify particle colonization rates, and we provide estimates of the grazing on attached bacteria by 1 of the species.

\section{MATERIALS AND METHODS}

We used 2 flagellates for our experiments, Bodo designis ( 8 to $10 \times 4$ to $6 \mu \mathrm{m}$ ) and Spumella sp. (ca. 10 $\mu \mathrm{m})$, that were isolated from sediments in the Wadden Sea. Both are known to attach to surfaces. The former feeds on attached bacteria (Caron 1987), while the latter feeds only on bacteria in free suspension. Cultures of flagellates were maintained on bacteria that were grown on wheat grains. All experiments were conducted at room temperature.

Motility patterns of Bodo designis and Spumella sp. Suspensions of either B. designis or Spumella sp. were added to a circular observation chamber $(\varnothing 15.9 \mathrm{~mm}$, height $2.45 \mathrm{~mm}$ ) that was glued with stopcock grease onto a microscopic glass slide and closed by a coverslip. Swimming patterns were video-recorded under dark-field illumination in an inverted microscope using a $6.4 \times$ objective, yielding a viewing field of ca. $600 \times 700 \mu^{2}$. The recordings were stored directly in the computer and 2-dimension swimming tracks were digitized using LabView Software (DiMedia) and a time resolution of $0.04 \mathrm{~s}$. About 80 tracks were analyzed for each species. To characterize the motility pattern, the RMS (root mean square) net distance covered $(L)$ was plotted as a function of time $(t)$. If the motility can be described as a diffusion process, then, in 2 dimensions (Berg 1993):

$$
L=2 \sqrt{D} \sqrt{t}
$$

where $D$ is the equivalent diffusion coefficient. $D$ was estimated from regression analysis.

In other experiments, observation chambers either 2.45 or $4.85 \mathrm{~mm}$ high were filled with a dense suspension of Bodo designis ( 1 to $10 \times 10^{4}$ cells $\mathrm{ml}^{-1}$ ), and every 0.5 to $10 \mathrm{~min}$ the number of flagellates that had contacted or attached to the microscopic slide, $N(t)$, were enumerated within a $1 \times 1 \mathrm{~mm}^{2}$ square (Christensen-Dalsgaard \& Fenchel 2003). This provides another way of estimating an equivalent diffusion coefficient of the swimming flagellates, since (derived from Carslaw \& Jaeger 1959):

$$
N(t)=1 C_{0}\left[1-\frac{8}{\pi^{2}} \sum_{n=0}^{\infty} \frac{1}{(2 n+1)^{2}} \mathrm{e}^{-D(2 n+1)^{2} \pi^{2} t / 4 l^{2}}\right]
$$

where 1 is half the chamber height and $C_{0}$ is the initial concentration of cells in the chamber. Again, $D$ was estimated by fitting Eq. (2) to the observations by regression analysis.

Colonization of agar spheres. We used previously described methods to quantify particle colonization rates (Kiørboe et al. 2003). Briefly, $4 \mathrm{~mm}$ diameter agar spheres were used as model particles. These were fixed on drawn-out Pasteur pipettes and exposed to dense suspensions of flagellates ( 1 to $10 \times 10^{3}$ cells $\mathrm{ml}^{-1}$ ). The number of flagellates attached to the spheres was then followed over time by sampling duplicate or triplicate spheres at time intervals ranging from 15 min to several hours. Most incubations lasted 6 to $12 \mathrm{~h}$. All incubations were conducted in $2 \mathrm{l}$ beakers with up to 36 spheres. In some cases the spheres had been pre-colonized by bacteria, obtained either from cultures (Marinobacter Strain PCOB-2) or from raw sea water (from Gullmar Fjord, Sweden) that had been strained through a $1 \mu \mathrm{m}$ filter. Even in experiments using non-colonized spheres, bacteria introduced together with the flagellates (stemming from the cultures) rapidly colonized the spheres. Fourteen incubations involved Bodo designis and 5 incubations Spumella sp. Flagellates that have colonized a particle may detach again, and 3 experiments were designed to quantify detachment rates. Flagellates were allowed to colonize agar spheres overnight; these were then moved to either sterile-filtered or to $1 \mu \mathrm{m}$-strained seawater and the number of attached flagellates was monitored over time.

The accumulation of flagellates on agar spheres may be predicted from motility analysis, since the rate at which flagellates encounter and attach to a sphere is given by:

$$
\frac{\mathrm{d} F}{\mathrm{~d} t}=\beta_{t} F_{A} p
$$


where $F$ is the number of flagellates attached to the sphere, $F_{A}$ is the ambient concentration of flagellates (ind. $\mathrm{cm}^{-3}$ ), $p$ the probability of attachment following encounter with the sphere, and $\beta_{t}$ the encounter rate kernel $\left(\mathrm{cm}^{3} \mathrm{~s}^{-1}\right)$. If the motility of the flagellates can be described as a random walk, then the encounter rate kernel for a sphere of radius $a$ is (Kiørboe et al. 2002):

$$
\begin{gathered}
\beta_{t}=4 \pi D a\left(1+\frac{a}{(\pi D t)^{0.5}}\right) \Rightarrow \\
F_{t}=4 \pi D a F_{A} p t\left(1+\frac{2 a}{(\pi D t)^{0.5}}\right)
\end{gathered}
$$

where $D$ is the equivalent diffusivity of the flagellates. If the motility is rather characterized as linear swimming, then:

$$
\beta=\pi a^{2} v_{t} \Rightarrow F_{t}=\pi a^{2} v_{t} p F_{A} t
$$

where $v_{t}$ is the propagation velocity of the flagellate.

Bodo designis grazing on attached bacteria. Grazing rates were quantified by comparing bacterial development on agar spheres or agar-coated glass slides in the absence and presence of Bodo designis. Grazing on the surface of agar spheres was quantified using stained bacteria. Bacteria were first allowed to colonize agar spheres; the bacteria were either prestained with Sybrgold for $2 \mathrm{~h}$, or entire spheres with attached bacteria were submerged in 1:10 000 diluted Sybrgold solution for $2 \mathrm{~h}$. Half the spheres were then moved to a dense suspension of $B$. designis and the other half to sterile filtered seawater and the abundance of attached stained and unstained bacteria (visualized by DAPI) as well as attached $B$. designis were monitored for 3 to $8 \mathrm{~h}$ on both sets of spheres. Grazing of stained bacteria was computed as the difference in density of attached (stained) bacteria in the absence and presence of $B$. designis. We did 4 incubations of this type.

In the other approach, agar-coated slides were first incubated for 0 to $48 \mathrm{~h}$ with raw seawater collected from the Øresund (Denmark); during this time, bacteria colonized the slides. We then transferred 10 slides to each of two $100 \mathrm{ml}$ beakers containing a dense culture of Bodo designis (and bacteria). To one of the beakers, eukaryotic inhibitors were added $\left(200 \mathrm{mg} \mathrm{l}^{-1}\right.$ each of colchicine and cycloheximide; Hahn \& Höfle 1999). In the non-inhibited beaker, the flagellates rapidly colonized the slides, and densities of between 4000 and 6000 cells cm$^{-2}$ were typically reached within $1 \mathrm{~h}$, remaining at that density for the remainder of the 4 to $8 \mathrm{~h}$ incubation period. Slides were sampled once every $30 \mathrm{~min}$ to $1 \mathrm{~h}$, and bacterial and flagellate densities were assessed by epifluorescence microscopy after DAPI staining.
Assuming a constant colonization rate of bacteria and constant mortality of attached bacteria due to flagellate grazing, the change in bacterial density $\left(B_{\text {, }}\right.$ cells $\left.\mathrm{cm}^{-2}\right)$ on the slides due to colonization $(K$, cells $\left.\mathrm{cm}^{-2} \mathrm{~h}^{-1}\right)$, specific growth and detachment $(\mu$ and $\delta$, both in units of $\left.\mathrm{h}^{-1}\right)$, and grazing mortality $\left(g, \mathrm{~h}^{-1}\right)$ can be described as (cf. Kiørboe et al. 2003):

$$
\frac{\mathrm{d} B}{\mathrm{~d} t}=K+\mu B-\delta B-g B=K-(\delta-\mu+g) B
$$

Replacing $d=\mu-\delta$ and integrating yields:

$$
B_{t}=B_{0} \mathrm{e}^{-(d+g) t}+\frac{K}{(d+g)}\left(1-\mathrm{e}^{-(d+g) t}\right)
$$

where $B_{0}$ is the initial bacterial density. Colonization, growth, and detachment of attached bacteria were assumed to be identical between parallel grazed and non-grazed beakers, and Eq. (7) was fitted to observed bacterial densities as a function of time, allowing estimation of grazing mortality (least-squares method). Grazing mortality divided by flagellate density yields an estimate of flagellate clearance rate $\left(\mathrm{cm}^{2} \mathrm{~h}^{-1}\right)$, and clearance multiplied by bacterial density an estimate of ingestion rate (nos. of bacteria eaten flagellate ${ }^{-1} \mathrm{~h}^{-1}$ ). We conducted 14 such grazing experiments.

The impact of flagellate grazing on attached bacteria was finally assessed by incubating agar spheres in $1 \mu \mathrm{m}$-strained seawater with and without Bodo designis. Spheres were sampled 3 times $\mathrm{d}^{-1}$ over $3 \mathrm{~d}$ for enumeration of attached bacteria and flagellates.

\section{RESULTS}

\section{Motility patterns}

Bodo designis and Spumella sp. have very different swimming patterns (Fig. 1). B. designis swims with an anterior flagellum and 'wriggles' through the water along an erratic track (Fig. 1A) at an average velocity of about $35 \mu \mathrm{m} \mathrm{s}^{-1}$. The real average velocity in 3 dimensions can be estimated as 1.22 times the average 2-dimensional velocity (Kiørboe et al. 2002). Spumella sp. also swims with an anterior flagellum that pulls the cell through the water, but along a smooth helical track at about $100 \mu \mathrm{m} \mathrm{s}^{-1}$ (Fig. 1B). The amplitude and the frequency of the helix vary substantially and inversely with each other, from about 20 to $120 \mu \mathrm{m}$ and 0.1 to $1.3 \mathrm{~s}^{-1}$, respectively (Fig. 2).

The swimming patterns can be further characterized by examining the net distance covered as a function of time (Fig. 3). In Bodo designis, the RMS net distance covered $(L)$ initially increases linearly with time $(t)$ (slope equal to swimming speed $=35 \mu \mathrm{m} \mathrm{s}^{-1}$ ) but, at scales exceeding $2 \mathrm{~s}$ and ca. $70 \mu \mathrm{m}$, the distance in- 

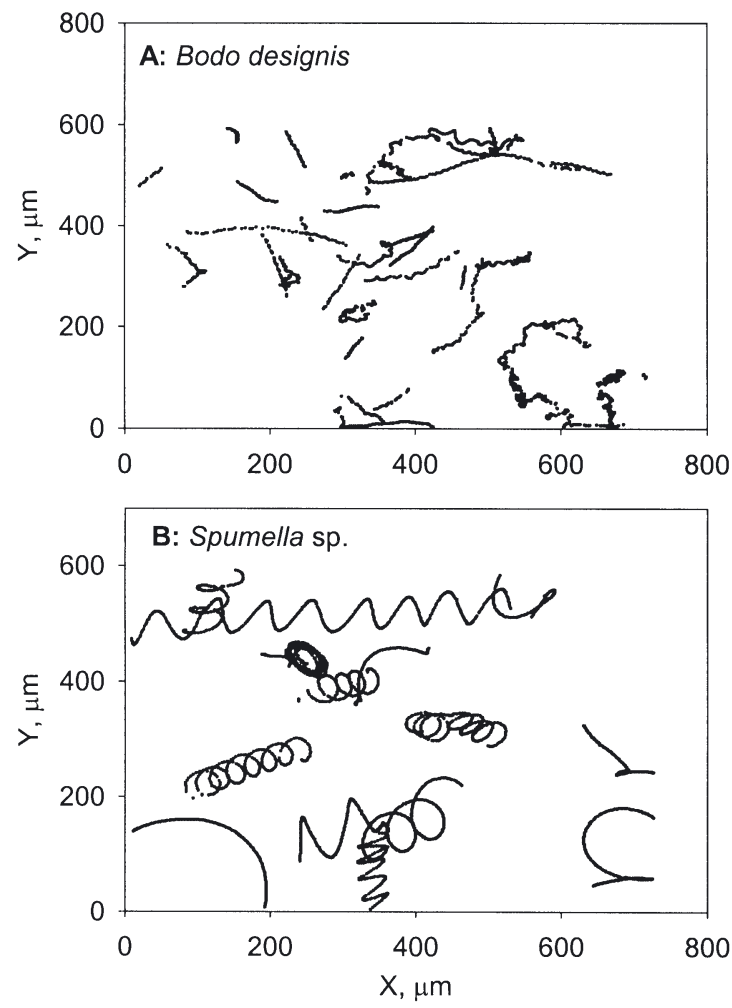

Fig. 1. (A) Bodo designis and (B) Spumella sp. swimming tracks. Positions are plotted at $0.04 \mathrm{~s}$ intervals

creases as a power function of time, with a power of about 0.5 (Fig. 3A,B). Thus, at these larger scales the motility pattern can be described as random and characterized by an equivalent diffusion coefficient. Eq. (1) was fitted to the data ( $t>2 \mathrm{~s}$ ), and $D$ was estimated as $0.7 \times 10^{-5} \mathrm{~cm}^{2} \mathrm{~s}^{-1}$.

In Spumella sp. there also appear to be 2 phases in the RMS distance covered as a function of time, but these are both linear (i.e. they have slopes of $\sim 1$ in log plots); the initial slope corresponds to the average swimming velocity $\left(V_{i}\right)$, while the latter slope corresponds to the tangential swimming velocity $\left(v_{t}\right)$, i.e. the velocity along the helical axis (Fig. 3C,D). For a perfect helical pattern the 2 are related as (Svenssen \& Kiørboe 2000):

$$
v_{i}=\sqrt{v_{t}^{2}+(2 \pi f A)^{2}}
$$

where $f$ and $A$ are the frequency and amplitude, respectively, of the helical pattern. $f A$ can be estimated from Fig. 2 as ca. $16.7 \mu \mathrm{m} \mathrm{s}^{-1}$, and $v_{t}$ as $16.5 \mu \mathrm{m} \mathrm{s}^{-1}$ in 2 dimensions (20.1 $\mu \mathrm{m} \mathrm{s}^{-1}$ in 3 dimensions) from Fig. 3C. Eq. (8) predicts a swimming velocity of $107 \mu \mathrm{m} \mathrm{s}^{-1}$ in 3 dimensions, corresponding to $88 \mu \mathrm{m} \mathrm{s}^{-1}$ in 2 dimensions. Thus, at spatial scales up to at least $400 \mu \mathrm{m}$ (due to the limited field of view, we could not extend the analysis to larger scales) Spumella sp. propagates essentially linearly with an average propagation velocity of $20 \mu \mathrm{m} \mathrm{s}^{-1}$.

The equivalent diffusivity of Bodo designis was also estimated from the rate at which the cells attach to a microscope slide (Fig. 4). Depending on the size of the chamber most cells had attached to a surface within 15 to $60 \mathrm{~min}$. Not all flagellates attached immediately upon contact with the glass slide; initially, most moved around on the surface of the slide until eventually attaching with the posterior flagellum. In 10 trials the average diffusivity estimated by fitting Eq. (2) to the data was $0.8 \pm 0.4 \times 10^{-5} \mathrm{~cm}^{2} \mathrm{~s}^{-1}$ (range: 0.5 to $1.9 \mathrm{~cm}^{2} \mathrm{~s}^{-1}$ ).

\section{Particle colonization}

The Bodo designis colonization pattern was characterized in all cases by an initial increase in the number of attached flagellates, followed by a period in which the number of attached flagellates remained more or less constant (Fig. 5A). There were no consistent differences in colonization pattern between spheres with and without bacteria, nor did the pattern vary consistently with the type of bacteria that had pre-colonized. Using the estimated diffusivity of $0.8 \times 10^{-5} \mathrm{~cm}^{2} \mathrm{~s}^{-1}$, Eq. (4) predicts the initial accumulation of flagellates well (assuming an attachment probability of $p=1$ ). The insignificant detachment of $B$. designis cells from the agar spheres (Fig. 5B) and the independence of the density of attached flagellates from ambient concentrations (Fig. 5C) suggest that the attachment probability declines with increasing density of attached flagellates. Apparently, B. designis' attachment probability approaches zero as its density approaches 2000 cells per sphere $\left(=4000\right.$ cells $\left.\mathrm{cm}^{-2}\right)$. In 1 incubation lasting $3 \mathrm{~d}$, flagellate density was constant for $40 \mathrm{~h}$ subsequent

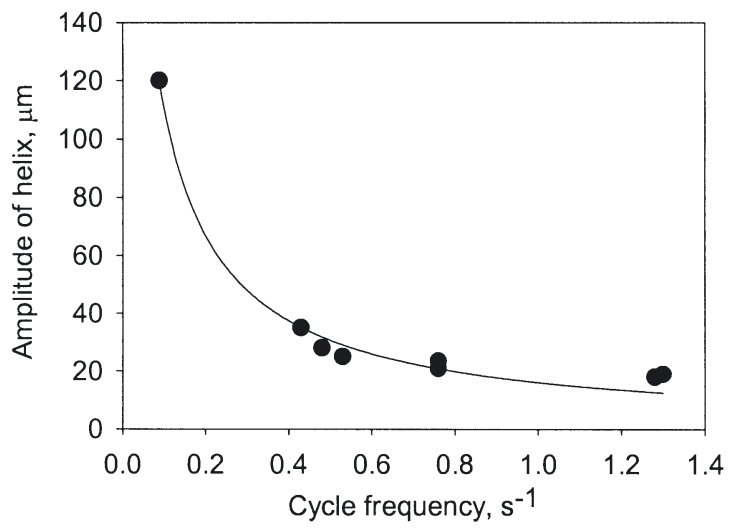

Fig. 2. Spumella sp. Relation between amplitude $(A, \mu \mathrm{m})$ and frequency $\left(f, \mathrm{~s}^{-1}\right)$ of swimming helixes. Hyperbolic relation is fitted to the data: $A=17.0 /(0.054+f), \mathrm{R}^{2}=0.99$ 
Fig. 3. Bodo designis and Spumella sp. Motility analyses: RMS net distance covered as a function of time. B. designis: data plotted on (A) linear and (B) $\log$ scales; Spumella sp.: data plotted on (C) linear and (D) log scales. Lines are regressions fitted to data shown by open symbols (dashed lines) or filled symbols (continuous lines). Grey symbols not included in regressions


Fig. 4. Bodo designis. Examples of flagellates colonizing glass slides, showing density of flagellates on glass bottom of (A) small and (B) large chambersmeasuring 2.45 or $4.85 \mathrm{~mm}$ in height-as a function of incubation time. Eq. (4) has been fitted to the data. Initial chamber concentration of cells $\left(C_{0}\right)$ and estimated $D$-values are given


to initial colonization, and then increased almost 10fold during the subsequent $40 \mathrm{~h}$.

The overall colonization pattern of Spumella sp. resembled that of Bodo designis (Fig. 6A). The initial increase was linear over time as predicted by Eq. (5), and the slope is an estimate of the colonization rate. Initial colonization rates taken from all 5 experiments were proportional to the ambient concentration of flagellates (Fig. 6B); the proportionality constant is an estimate of the encounter rate kernel $\times$ the attachment probability, $\beta \times p=0.11 \mathrm{ml} \mathrm{h}^{-1}=3 \times 10^{-5} \mathrm{ml} \mathrm{s}^{-1}$. $\beta$ can also be estimated from motility analysis as $\beta=\pi a^{2} v_{t}=$ $2.5 \times 10^{-4} \mathrm{ml} \mathrm{s}^{-1}$. Thus, attachment probability can be estimated as $\mathrm{p}=3 / 25=0.12=12 \%$. As for $B$. designis, cell accumulation leveled off subsequent to initial colonization. However, in contrast to $B$. designis, Spumella sp. detaches rapidly from the particles (Fig. 6C, specific detachment rate $=0.4 \mathrm{~h}^{-1}$ ). Assuming a constant detachment rate, $\delta$, Eq. (5) modifies to (Kiørboe et al. 2002):

$$
F_{t}=\frac{\beta p F_{A}}{\delta}\left(1-\mathrm{e}^{-\delta t}\right)
$$

Eq. (9) provides a good fit to the data (Fig. 6A), and the estimated detachment rate $0.68 \mathrm{~h}^{-1}$ (range 0.66 to 0.70 $\mathrm{h}^{-1}$ ) was within a factor of 2 of that estimated directly.

\section{Bodo designis grazing rates on attached bacteria}

After attachment to a surface by the tip of the posterior flagellum, Bodo designis stretches by up to $25 \mu \mathrm{m}$ from its attachment point in all directions and collects bacteria within this area by means of its anterior flagellum. Even when attached, however, the cell moves forward slowly - gliding at the tip of the flagellum - 

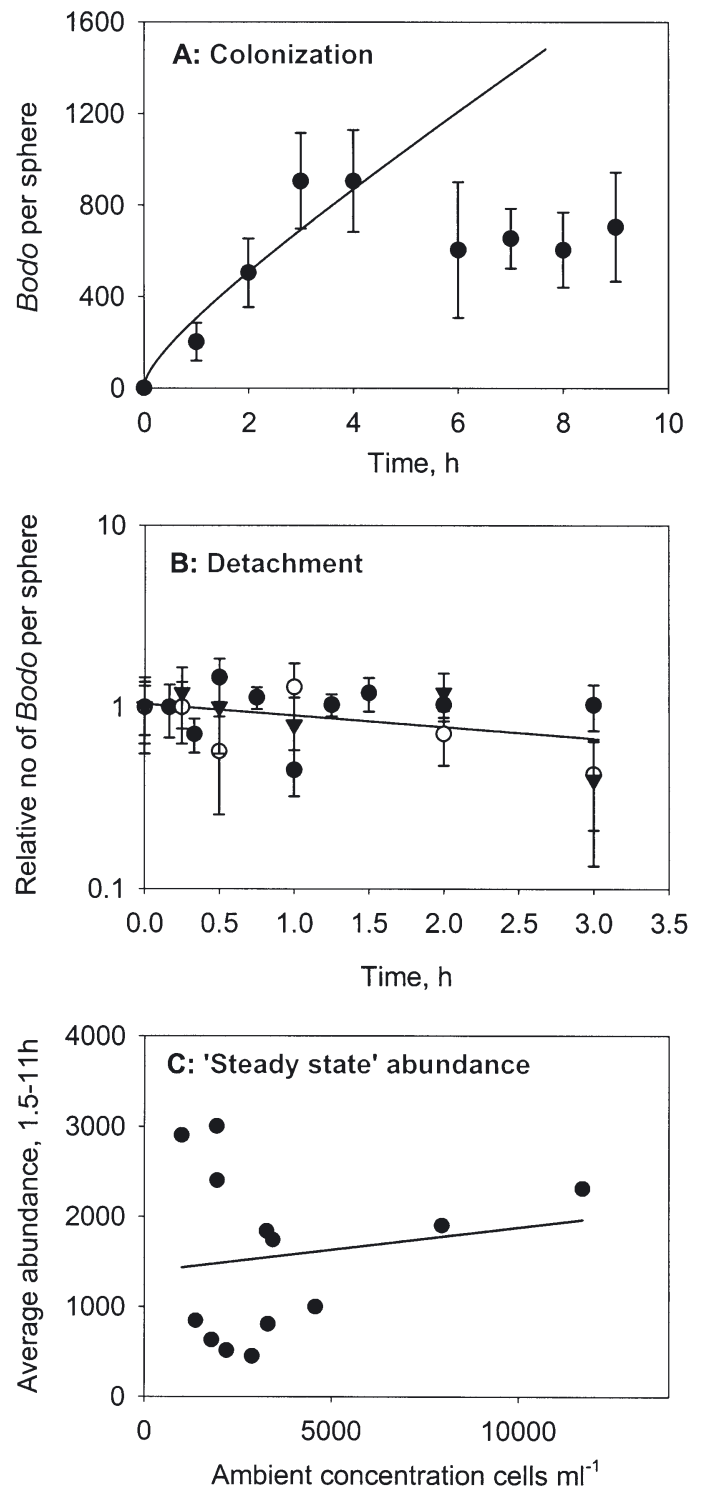

Fig. 5. Bodo designis. (A) Example of initial colonization of agar sphere. The line is the predicted colonization (Eq. 4) assuming $D=0.8 \times 10^{-5} \mathrm{~cm}^{2} \mathrm{~s}^{-1}$. (B) Detachment of $B$. designis from agar spheres. Data from 3 experiments have been normalized by the initial abundance of cells per sphere and plotted together (each experiment has a different symbol). The line is the regression of the pooled data; the regression is not significant. (C) Average abundance of attached flagellates in 15 experiments following initial colonization as a function of ambient concentration of flagellates. The line is the regression, which is not significant. Error bars are $\pm 1 \mathrm{SE}$

at an average velocity of $2.7( \pm 1.3) \mu \mathrm{m} \mathrm{s}^{-1}$, thus collecting bacteria within an approximate area per unit time of $50 \times 2.7 \mu \mathrm{m}^{2} \mathrm{~s}^{-1} \approx 5 \times 10^{-3} \mathrm{~cm}^{2} \mathrm{~h}^{-1}$.

The presence of flagellates had in all cases a significant negative effect on the number of attached bacteria, both on the spheres and on the slides (Figs. 7 \& 8). On the spheres, the cumulative number of bacteria
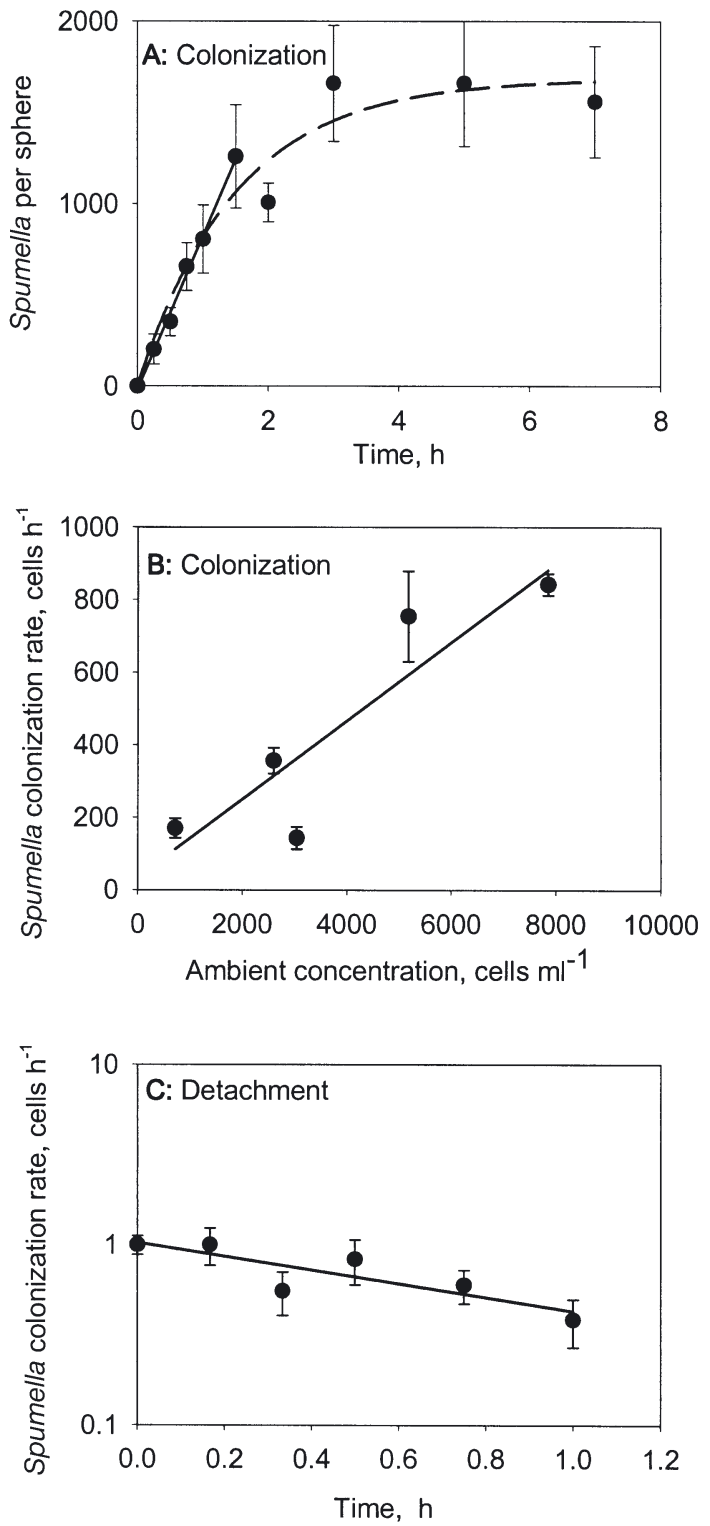

Fig. 6. Spumella sp. (A) Example of colonization of agar sphere. Continuous line is a fit of Eq. (5) utilizing only the initial data points, while the dashed line is a fit of Eq. (9) utilizing all data; (B) colonization rate versus ambient concentration of flagellates. The fitted linear regression has an estimated slope of $0.11 \pm$ $0.03 \mathrm{ml} \mathrm{h}^{-1}\left(\mathrm{R}^{2}=0.81\right)$. (C) Detachment of Spumella sp. from agar spheres. Data normalized by the initial abundance of cells per sphere. The regression line (log cells per sphere vs time) is significant and yields an estimated detachment rate of $0.38 \pm 0.12 h^{-1}\left(R^{2}=0.73\right)$. Error bars are $\pm 1 \mathrm{SE}$

grazed (difference in number of attached stained bacteria between spheres incubated in sterile filtered seawater and in the presence of Bodo designis) was approximately linearly related to the cumulative number of 'flagellate-hours' (= cumulated abundance of flagellates $\times$ time) (Fig. 7), and specific ingestion rates were estimated as the slopes of these plots. 

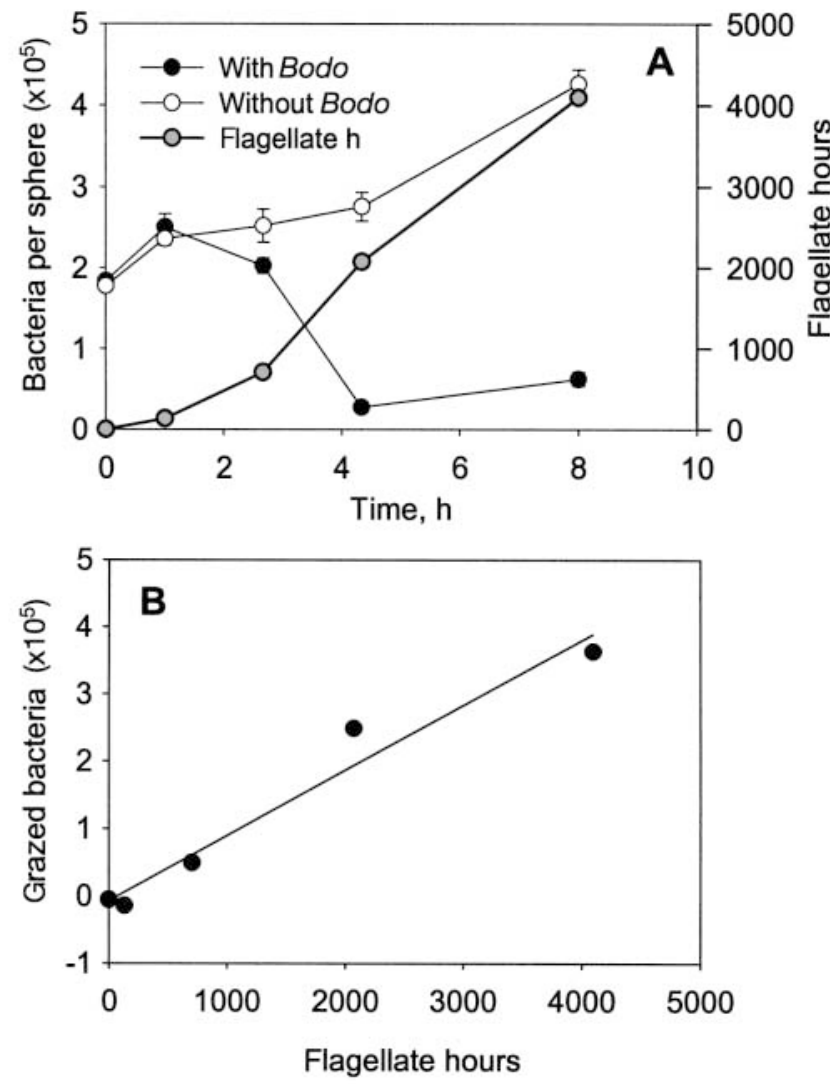

Fig. 7. Example of Bodo designis grazing on bacteria attached to agar sphere. (A) Evolution of abundance of stained bacteria on spheres in absence and presence of flagellates and of number of 'flagellate hours'. (B) Estimated number of grazed bactera versus 'flagellate hours'; slope of the regression is an estimate of the grazing rate: $97 \pm 10$ bacteria flagellate ${ }^{-1} \mathrm{~h}^{-1}$ $\left(\mathrm{R}^{2}=0.96\right)$. Error bars in $(\mathrm{A})$ are $\pm 1 \mathrm{SE}$

In the experiments with unstained bacteria and inhibited flagellates, 3 different patterns were seen, depending on bacterial density and growth, and on flagellate grazing rates: (1) density of attached bacteria decreased in grazing beakers and increased in nongrazed controls (Fig. 8A); (2) density of attached bacteria increased on both grazed and non-grazed slides but reached near steady-state, at least in the grazing beaker (Fig. 8B); (3) bacterial density increased nearexponentially on both types of slides (Fig. 8C). While Eq. (7) provided good fits to all 3 types of experimental data, parameter estimates were strongly intercorrelated in the latter case, rendering such estimates meaningless; these estimates were disregarded.

Combining the various grazing estimates yields the functional response in ingestion and clearance rates to variation in density of attached bacteria (Fig. 9). Ingestion rates increased with bacterial density and ranged up to 120 bacteria flagellate $\mathrm{b}^{-1}$. The functional response was described by fitting Holling's disk equa- tion (Holling 1959) to the data (Fig. 9). From the fit, a 'handling time' of ca. $30 \mathrm{~s}$ and a maximum surface clearance rate of $1.3 \times 10^{-4} \mathrm{~cm}^{2} \mathrm{~h}^{-1}$ was estimated.

The impact of flagellate grazing on attached bacteria was finally evaluated by comparing the population development of attached bacteria in the absence and presence of Bodo designis (Fig. 10). Throughout (ca. $80 \mathrm{~h}$ ), bacterial density on the spheres was higher in the absence than in the presence of flagellates. Bacteria also appeared to be much more aggregated on the surface of spheres in the presence of flagellates (Fig. 11).


Fig. 8. Examples of Bodo designis grazing on bacteria attached to agar-coated glass slides: evolution of number of attached bacteria with $(\bullet)$ and without $(O)$ addition of eukaryotic inhibitors. Examples shown are 1 of each of the 3 patterns observed. Lines are fits of Eq. (7) to the data. Error bars are $\pm 1 \mathrm{SE}$ 

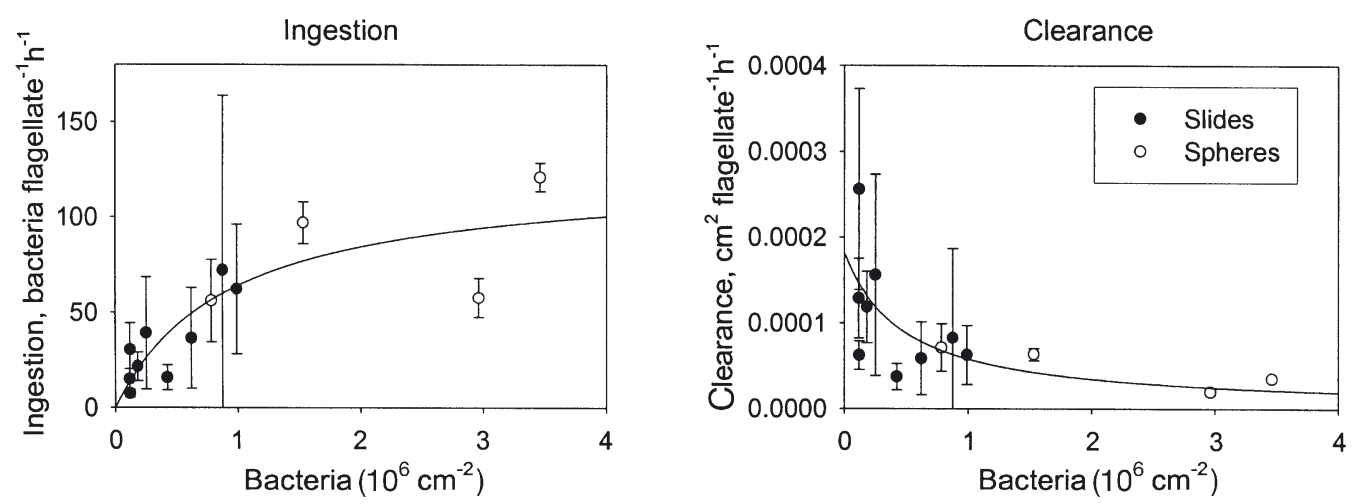

Fig. 9. Bodo designis. Functional response in ingestion rate and surface area clearance rate to variation in density of attached bacteria. Lines are fits of Holling's disk equation to the data. For ingestion rate $\left(I\right.$, bacteria flagellate $\left.{ }^{-1} \mathrm{~h}^{-1}\right)$ the relation is $I=a \times$ $B /(1-a \times \tau \times B)$, where $a$ is the instantaneous rate of prey discovery $\left(\mathrm{cm}^{2}\right.$ flagellate $\left.\mathrm{e}^{-1} \mathrm{~h}^{-1}\right), \tau$ is the prey handling time (h), and $B$ is the density of bacteria (bacteria $\mathrm{cm}^{-2}$ ). The fitted parameters are $a=1.3 \pm 0.5 \times 10^{-4} \mathrm{~cm}^{2}$ flagellate $\mathrm{h}^{-1}$, and $\tau=0.0081 \pm 0.0017 \mathrm{~h}$ $\left(\mathrm{R}^{2}=0.74\right)$. Error bars are $\pm 1 \mathrm{SE}$

\section{DISCUSSION}

\section{Colonization}

Marine snow aggregates are inhabited by dense microbial communities. Flagellates, for example, occur in abundances of 10 to 10000 per aggregate, increasing with increasing aggregate size (see data compilation by Kiørboe 2001). Particles suspended in natural seawater in the laboratory will be colonized by flagellates, but typically these occur in detectable abundances only after 1 to several days of incubation (e.g. Stuart et al. 1981, Pomeroy et al. 1984, Biddanda \& Pomeroy 1988). In contrast, the flagellate colonization rates reported here suggest that high densities would be reached within a few hours. However, neither of these laboratory rates are immediately applicable to field situations, owing to differences in ambient flagellate densities and in the flow environment. Microorganisms, including flagellates, colonize particles mainly because the organisms are motile. Even a rapidly sinking aggregate will scavenge only a few suspended immobile organisms, because the aggregate pushes the water away as it sinks. However, advection may facilitate encounters between sinking aggregates and microorganisms that have motilities that can be described as a diffusion process. The enhancement can be estimated from the Sherwood number and may be up to a factor of 20 for the largest and fastest sinking aggregates and for organisms with diffusivities similar to those estimated here for Bodo designis (Kiørboe et al. 2001). Many flagellates have chemosensory capabilities that may allow them to aggregate at food patches (Fenchel \& Blackburn 1999) and further enhance the rate at which they colonize marine snow aggregates. The effect of chemosensory behavior is, however, somewhat limited in a sinking aggregate because advection washes any signals away (Kiørboe \& Jackson 2001). Characteristic concentrations of flagellates in the euphotic zone are on the order of $10^{3}$ cells $\mathrm{ml}^{-1}$. If they have motilities similar to those observed here for $B$. designis, then a $0.5 \mathrm{~cm}$ radius sinking aggregate will
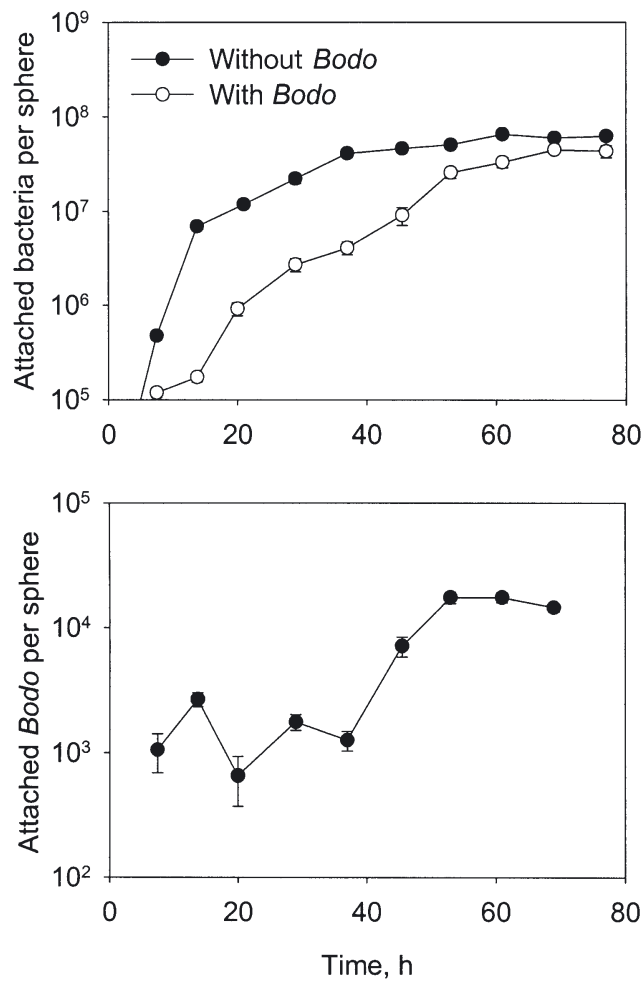

Fig. 10. Long-term effect of Bodo designis grazing on bacterial populations. (A) Number of attached bacteria in the presence and absence of flagellates as a function of time. (B) Number of attached flagellates as a function of time. Error bars are $\pm 1 \mathrm{SE}$ 

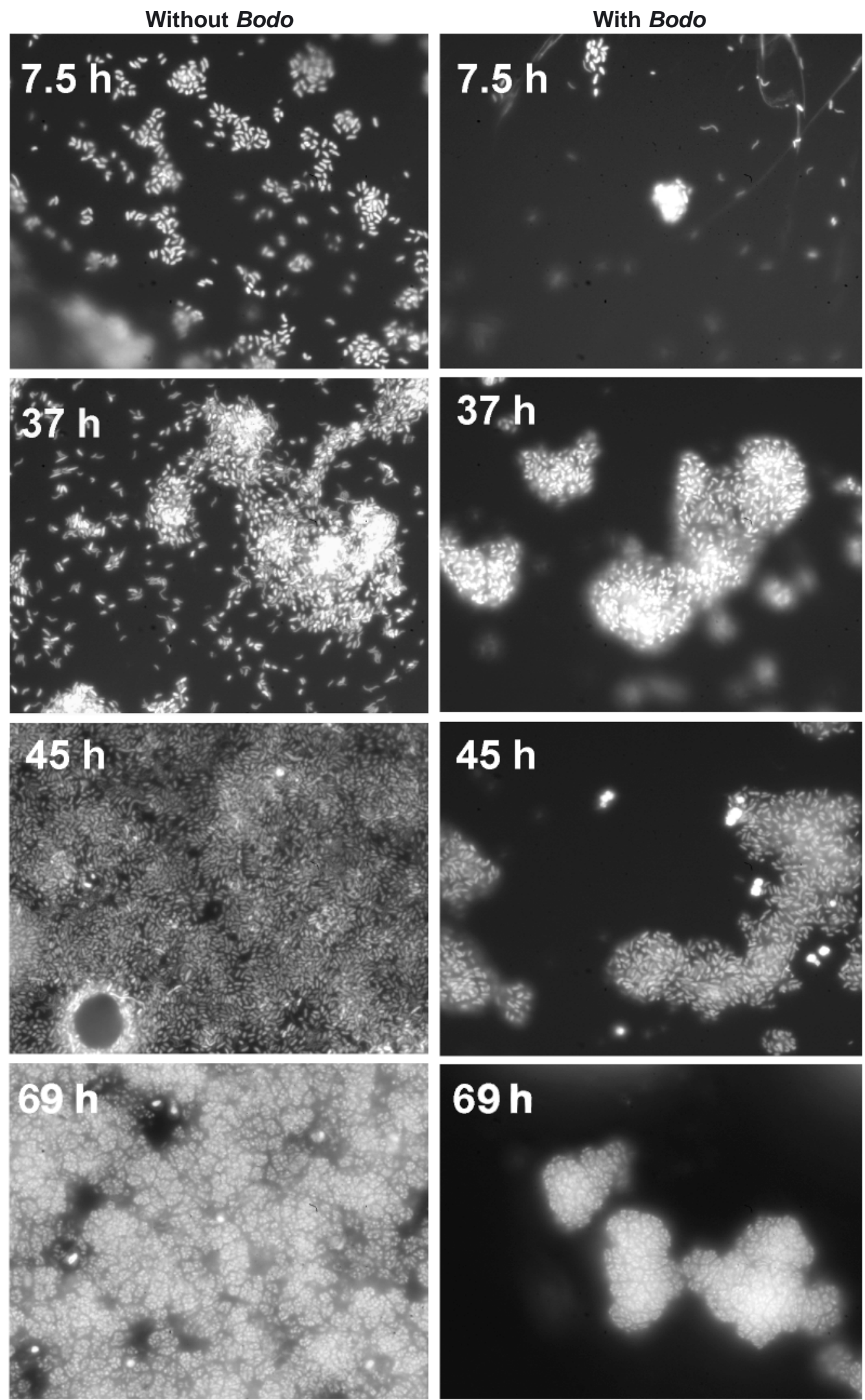

Fig. 11. Bacteria on the surface of spheres in the absence (left) and presence (right) of Bodo designis after 7.5, 37, 45 and 69 $\mathrm{h}$ incubation 
encounter about 2000 flagellates $\mathrm{h}^{-1}$ (Eq. 5, assuming a Sherwood number of 10 estimated from Kiørboe et al. 2001). Thus, typical abundances of attached flagellates may be reached quickly, and the abundance of attached flagellates is probably rarely limited by encounter rates. Rather, abundances of attached flagellates may be governed by attachment and detachment probabilities, e.g. mediated through grazing possibilities on the aggregate.

\section{Grazing}

The surface clearance rate is the imaginary surface area cleared of bacteria per flagellate per unit time. The estimated area potentially covered by a Bodo designis cell gliding on a surface is 10 to 100 times the estimated surface clearance rate, suggesting that $B$. designis collects or ingests only a small fraction of the bacteria encountered.

The bacterial ingestion rates estimated here, 5 to 120 bacteria flagellate $\mathrm{h}^{-1}$, are similar to or somewhat higher than the few earlier reports on flagellate grazing rates on attached bacteria. The only previous estimates of flagellate grazing on bacteria attached to marine snow are 1 to 10 bacteria flagellate $\mathrm{h}^{-1}$ for Bodo designis (Artolozaga et al. 2002) and 15 bacteria flagellate ${ }^{-1} \mathrm{~h}^{-1}$ for an assemblage of small $(\sim 5 \mu \mathrm{m})$ flagellates (Kiørboe et al. 2003). Fenchel (1986) reported a functional response for Bodo sp. that was very similar to that found here. Other reports on flagellate grazing on sediment-attached bacteria range up to 75 bacteria flagellate $^{-1} \mathrm{~h}^{-1}$ (Starink et al. 1994, 1996, Epstein 1997, Hammels et al. 2001). Because B. designis has a biovolume about 200 times the biovolume of its bacterial prey (1 to $2 \mu \mathrm{m}$ length), and assuming a growth yield of 0.4 , the present maximum grazing estimates would predict a maximum flagellate growth rate of about $0.2 \mathrm{~h}^{-1}$. This is similar to that found in free-living, bacterivorous pelagic flagellates (Fenchel 1982).

\section{Dynamics of attached microbes}

After initial colonization, the accumulation of both Bodo designis and Spumella sp. leveled off when abundances had reached about 2000 cells per sphere $\left(=4000\right.$ cells $\left.\mathrm{cm}^{-2}\right)$, and remained at that density for up to $40 \mathrm{~h}$ (Fig. 10). A similar stationary density was reached rapidly on the agar-coated glass slides exposed to culture concentrations of B. designis. Such flagellate densities are typical also of marine snow aggregates (see data compilation by Kiørboe 2001). The mechanisms controlling the abundance of attached flagellates during this 'stationary phase' appeared to be different between the 2 species and to be caused by, respectively, a density-dependent attachment probability and a constant specific detachment rate. $B$. designis grazes on attached bacteria, and density-dependent attachment may be interpreted in the context of possible intraspecific competition. The maximum surface clearance rate of $10^{-4} \mathrm{~cm}^{2}$ flagellate ${ }^{-1} \mathrm{~h}^{-1}$ at 4000 flagellates $\mathrm{cm}^{-2}$ implies a specific mortality rate of attached bacteria of $0.4 \mathrm{~h}^{-1}\left(=10 \mathrm{~d}^{-1}\right)$. This is higher than typical specific growth rates of bacteria attached to natural marine snow aggregates, which are rather on the order of $2 \mathrm{~d}^{-1}$ (Grossart \& Ploug 2001, Grossart et al. 2003a). However, bacteria colonization also occurs from the ambient water. With typical bacterial motilities $\left(D=10^{-5} \mathrm{~cm}^{2} \mathrm{~s}^{-1}\right.$, e.g. Berg 1993) and ambient concentrations $\left(10^{6} \mathrm{ml}^{-1}\right)$, bacteria would arrive at a rate of $10^{5}$ cells $\mathrm{h}^{-1}$ at the surface of a $4 \mathrm{~mm}$ diameter sphere, accounting for about half of the bacteria potentially ingested by the residing flagellates. Thus, bacterial grazing would approximately be balanced by bacterial growth and colonization under natural conditions. Higher grazing rates would lead to depletion of attached bacteria, or to a change in the bacterial community towards grazer-resistant forms, as seen in pelagic communities (Posch et al. 1999, Jürgens \& Matz 2002). Aggregation of bacterial cells on the sphere surface (Fig. 11) might similarly serve as grazer protection, because specific grazing rates would become saturated within patches. In the present experiments, protozoan grazing was unable to check the population of attached bacteria (Fig. 10), probably owing to their very high growth rate (in excess of $10 \mathrm{~d}^{-1}$; authors' own unpublished estimate based on thymidine incorporation). However, observed bacterial abundances on natural aggregates are on the order of $10^{6}$ bacteria per aggregate rather than the $10^{8}$ bacteria found here on the model aggregates (Fig. 10), and the above considerations thus suggest that populations of bacteria attached to natural aggregates would be checked by flagellate grazing.

The implications of bacterial grazing go beyond population dynamics, since it may also lead to changes in regeneration rates (Pomeroy et al. 1984, Rothhaupt \& Güde 1992). For example, Sala \& Güde (1999) found that heterotrophic nanoflagellates play an important role during the degradation of macrophytes because they grazed mainly on free bacteria and left the attached bacteria to grow. This promoted a shift from the hydrolysis of non-structural to structural polysaccharides. Hence, zooplankton and especially microzooplankton grazing may lead to pronounced changes in rates of bacterial uptake and remineralization of organic matter.

The dynamics of the microbial communities that develop on marine snow aggregates are governed by a 
multitude of processes, including colonization, grazing interactions, other inter- and intra-specific interactions, and growth (Azam \& Long 2001, Long \& Azam 2001, Gram et al. 2002, Grossart et al. 2003b, Kiørboe et al. 2003). Attempts to model microbial dynamics with the longer-term aim of describing material fluxes and vertical transport in the upper ocean are constrained by our limited knowledge of the component processes (Kiørboe 2003). The present study demonstrates that flagellates may rapidly colonize sinking aggregates, and that their grazing on attached bacteria may have significant influence on the attached microbial community and, therefore, on the fate of the aggregate. Grazer-induced changes in bacterial numbers and community composition may cause changes in nutrient regeneration and organic matter remineralization. Thus, while the activity of the attached microbial populations is ultimately limited by their abundances and dynamics - which we can now describe - the exact effects of bacterial grazing on aggregate degradation remain to be revealed.

Acknowledgements. We are grateful to Dr. Uffe H. Thygesen for writing MatLab codes for the regression analyses. This work was supported by grants from the Danish Natural Science Research Council to T.K. (21-01-054), from the Leibniz Society to H.P.G., and by EU-funded Access to the Research Infrastructure Kristineberg Marine Research Station (ARI P.45).

\section{LITERATURE CITED}

Alldredge AL, Silver MW (1984) Characteristics, dynamics and significance of marine snow. Prog Oceanogr 20:41-82

Artolozaga I, Ayo B, Latatu A, Azíua I, Unanue M, Iberri J (2000) Spatial distribution of protists in the presence of macroaggregates in marine systems. FEMS Microbiol Ecol 33:191-196

Artolozaga I, Valcárel M, Ayo B, Latatu A, Iberri (2002) Grazing rates of bacterivorous protists inhabiting diverse planktonic environments. Limnol Oceanogr 47:142-150

Azam F, Long RA (2001) Oceanography - sea snow microcosms. Nature 414:495-496

Barbara GM, Mitchell JG (2003) Marine bacterial organisation around point-like sources of amino acids. FEMS Microbiol Ecol 43:99-109

Berg HC (1993) Random walks in biology. New, expanded edition. Princeton University Press, Princeton, NJ

Biddanda BA, Pomeroy LR (1988) Microbial aggregation and degradation of phytoplankton-derived detritus in seawater. I. Microbial succession. Mar Ecol Prog Ser 42:79-88

Caron DA (1987) Grazing of attached bacteria by heterotrophic microflagellates. Microb Ecol 13:203-218

Caron DA (1991) Heterotrophic flagellates associated with sedimenting detritus. In: Patterson DJ, Larsen J (eds) The biology of free-living heterotrophic flagellates, Spec Vol 45. The Systematics Association, Clarendon Press, Oxford, p 77-92

Caron DA, Davis PG, Madin LP, Sieburth JMcN (1986) Enrichment of microbial populations in macroaggregates (marine snow) from surface waters of the North Atlantic. J Mar Res 44:543-565

Carslaw HS, Jaeger JC (1959) Conduction of heat in solids, 2nd edn. Clarendon Press, Oxford

Christensen-Dalsgaard KK, Fenchel T (2003) Increased filtration efficiency of attached compared to free-swimming flagellates. Aquat Microb Ecol 33:77-86

Epstein SS (1997) Microbial food webs in marine sediments. I. Trophic interactions and grazing rates in two tidal flat communities. Microb Ecol 34:188-198

Fenchel T (1982) Ecology of heterotrophic microflagellates. II. Bioenergetics and growth. Mar Ecol Prog Ser 8:225-231

Fenchel T (1986) The ecology of heterotrophic microflagellates. Adv Microb Ecol 9:57-97

Fenchel T, Blackburn N (1999) Motile chemosensory behaviour of phagotrophic protests: mechanisms for and efficiency in congregating at food patches. Protist 150: 325-336

Gram L, Grossart HP, Schlingloff A, Kiørboe T (2002) Possible quorum sensing in marine snow bacteria: production of acylated homoserine lactones by Roseobacter strains isolated from marine snow. Appl Environ Microbiol 68: 4111-4115

Grossart HP, Ploug H (2001) Microbial degradation of organic carbon and nitrogen on diatom aggregates. Limnol Oceanogr 46:267-277

Grossart HP, Riemann L, Azam F (2001) Bacterial motility in the sea and its biogeochemical implications. Aquat Microb Ecol 25:247-258

Grossart HP, Hietanen S, Ploug H (2003a) Microbial dynamics on diatom aggregates in Øresund, Denmark. Mar Ecol Prog Ser 249:69-78

Grossart HP, Kiørboe T, Tang K, Ploug H (2003b) Bacterial colonization of particles: growth and interactions. Appl Environ Microbiol 69:3500-3509

Güde H (1986) Loss process influencing growth of planktonic bacterial populations in Lake Constance. J Plankton Res 8: 795-810

Hahn MW, Höfle MG (1999) Flagellate predation on a bacterial model community: interplay of size-selective grazing, specific bacterial cell size, and bacterial community composition. Appl Environ Microbiol 65:4863-4872

Hammels I, Muylaert K, Casteleyn G, Vyverman W (2001) Uncoupling of bacterial production and flagellate grazing on aquatic sediments: a case study from an intertidal flat. Aquat Microb Ecol 25:31-42

Holling CS (1959) Some characteristics of simple types of predation and parasitism. Can Entomol 91:385-398

Jackson GA (1989) Simulation of bacterial attraction and adhesion to falling particles in an aquatic environment. Limnol Oceanogr 34:514-530

Jürgens K, Matz C (2002) Predation as a shaping force for the phenotypic and genotypic composition of planktonic bacteria. Antonie Leeuwenhoek 81:413-434

Kiørboe T (2001) Formation and fate of marine snow: smallscale processes with large-scale implications. Sci Mar 65(Suppl):57-71

Kiørboe T (2003) Marine snow microbial communities: scaling of abundances with aggregate size. Aquat Microb Ecol 33: $67-75$

Kiørboe T, Jackson GA (2001) Marine snow, organic solute plumes, and optimal sensory behaviour of bacteria. Limnol Oceanogr 46:1309-1318

Kiørboe T, Ploug H, Thygesen UH (2001) Fluid motion and solute distribution around sinking aggregates. I. Small scale fluxes and heterogeneity of nutrients in the pelagic environment. Mar Ecol Prog Ser 211:1-13 
Kiørboe T, Grossart HP, Ploug H, Tang K (2002) Mechanisms and rates of bacterial colonization of sinking aggregates. Appl Environ Microbiol 68:3996-4006

Kiørboe T, Tang K, Grossart HP, Ploug H (2003) Dynamics of microbial communities on marine snow aggregates: colonization, growth, detachment, and grazing mortality of attached bacteria. Appl Environ Microbiol 69:3036-3047

Long R, Azam F (2001) Antagonistic interactions among marine pelagic bacteria. Appl Environ Microbiol 67: 4975-4983

Patterson DJ, Nygaard K, Steinberg G, Turley CM (1993) Heterotrophic flagellates and other protists associated with oceanic detritus throughout the water column in the mid North Atlantic. J Mar Biol Assoc UK 73:67-95

Ploug H, Grossart HP, Azam F, Jørgensen BB (1999) Photosynthesis, respiration, and carbon turnover in sinking marine snow from surface waters of Southern California Bight: implications for the carbon cycle in the ocean. Mar Ecol Prog Ser 179:1-11

Pomeroy LR, Hanson RB, McGillivary PA, Sherr BF, Kirchman D, Deibel D (1984) Microbiology and chemistry of fecal products of pelagic tunicates: rates and fates. Bull Mar Sci 35:426-439

Posch T, Šimek K, Vrba J, Pernthaler J, Nedoma J, Sattler B, Sonntag B, Psenner R (1999) Predator-induced changes of bacterial size-structure and productivity studied on an experimental microbial community. Aquat Microb Ecol 18: $235-246$

Editorial responsibility: John Dolan, Villefranche-sur-Mer, France
Rothhaupt KO, Güde H (1992) The influence of spatial and temporal concentration gradients on phosphate partitioning between different size fractions of plankton - further evidence and possible causes. Limnol Oceanogr 37: 739-749

Sala MM, Güde H (1999) Role of protozoans on the microbial ectoenzymatic activity during the degradation of macrophytes. Aquat Microb Ecol 20:75-82

Simon M, Grossart HP, Schweitzer B, Ploug H (2002) Microbial ecology of organic aggregates in aquatic systems. Aquat Microb Ecol 28:175-211

Smith DC, Simon M, Alldredge AL, Azam F (1992) Intensive hydrolytic activity on marine aggregates and implications for rapid particle dissolution. Nature 359:139-141

Starink M, Krylova IN, Bär-Gilisen MJ, Bak RP, Cappenberg TE (1994) Rates of benthic protozoan grazing on free and attached sediment bacteria measured with fluorescently stained sediment. Appl Environ Microbiol 60:2259-2264

Starink M, Bär-Gilisen MJ, Bak RPM, Cappenberg TE (1996) Bacterivory by heterotrophic nanoflagellates and bacterial production in sediments of a freshwater littoral system. Limnol Oceanogr 41:62-69

Stuart V, Lucas MI, Newell RC (1981) Heterotrophic utilisation of particulate matter from the kelp Laminaria pallida. Mar Ecol Prog Ser 4:337-348

Svensen C, Kiørboe T (2000) Remote prey detection in Oithona similis: hydromechanical versus chemical cues. J Plankton Res 22:1155-1166

Submitted: December 8, 2003; Accepted: January 30, 2004 Proofs received from author(s): April 16, 2004 